CLINICAL INVESTIGATIONS

\title{
COMPARISON OF THREE SKIN DISINFECTANT SOLUTIONS USED FOR SKIN PREPARATION PRIOR TO SPINAL AND EPIDURAL ANAESTHETIC PROCEDURES IN PARTURIENTS AT DE SOYZA MATERNITY HOSPITAL AND CASTLE STREET HOSPITAL FOR WOMEN.
}

\author{
B.P. Kudavidanage, ${ }^{1 *}$ T.D.C.P. Gunasekara, ${ }^{2}$ S.S.N. Fernando, ${ }^{2}$ D.F.D. Meedin, ${ }^{2}$ \\ A. Abayadeera ${ }^{1}$ \\ 1. National Hospital of Sri Lanka, Colombo, 2. Department of Microbiology, Faculty \\ of Medical Sciences, University of Sri Jayawardenepura, Gangodawila, Nugegoda. \\ * Corresponding author : E-mail: bimal_ladee@yahoo.co.uk
}

Key words: disinfectants, bacterial flora

\begin{abstract}
Background
Effective skin disinfection before spinal and epidural anaesthesia is essential to avoid bacterial infection. Three disinfectants, Betadine, Cetavlon and a combination of Chlorhexidine, Cetrimide and Isopropyl alcohol are used in hospitals as skin disinfectant solutions. We compared the ability of these disinfectant solutions to reduce the bacterial skin flora prior to anaesthetic procedures.
\end{abstract}

\section{Method}

80 Pregnant women admitted to Castle Street Hospital for Women (CSHW) and De Soysa Maternity Hospital (DMH) who received epidural or spinal anaesthesia were studied. They were randomly assigned to receive skin preparation with Betadine, Cetavlon and the combined preparation. Two cultures were obtained from each subject; just prior to skin disinfection and immediately following disinfection. In-use test was performed to determine bacterial contamination of newly opened and multiple used bottles from each group.

Results

The reduction in bacterial colony forming units (CFU) following application of disinfectant in all three groups were significant $(\mathrm{p}<0.05)$. The reduction of bacterial CFU following skin preparation between the three groups was tested by one way ANOVA and found to be significant $(\mathrm{P}=0.018)$. Pair wise comparison among Reduction of skin flora by antiseptics showed highest reduction with the use of the combined preparation. None of the samples of disinfectants obtained from newly opened and multiple used bottles of antiseptics were contaminated.

\section{Conclusion}

The combined preparation consisting of Chlorhexidine, Cetrimide and Iso propyl alcohol showed the best reduction of skin flora followed by Cetavlon and Betadine.

Epidural and spinal anesthesia are currently popular in Sri Lanka for labour analgesia and anaesthesia. These techniques involve invasive procedures that require effective skin disinfection before administration. The human skin harbours many commensal bacteria. Thus the skin may itself be a source of potential pathogens during such invasive procedures. ${ }^{1}$ Infection of invasive site may rarely result in epidural abcesses. Although rare, this condition may rapidly lead to meningitis, paralysis or death. ${ }^{2}$ Therefore in order to avoid bacterial contamination during the procedure, care must be taken to ensure that effective skin disinfection has been carried out 
and proper aseptic techniques are followed during administration of epidural and spinal anesthesia. In the Sri Lankan operation theater setting, skin disinfection is commonly carried out using solutions of $10 \%$ povidone iodine, $1 \%$ cetrimide or solutions of chlorhexidine prior to insertion of epidural catheters. It is common practice among anaesthetists to use these solutions from multi use bottles on the assumption that the solutions are free from bacterial contamination. However studies have indicated the presence of bacterial contamination in solutions used for skin disinfection in hospital settings. In a study conducted in USA, $40 \%$ of povidone iodine solutions from multi use bottles were contaminated with Staphylococcus, Bacillus or Pseudomonas. ${ }^{3}$ In Sri Lanka solutions such as cetrimide solutions, chlorhexidine and cetrimide antiseptic solutions are diluted to the in-use concentration and distributed to the operation theatres for use. Thus there is a possibility of contamination of both new and multi use bottles of these disinfectants.

Although povidone iodine is currently popular as a skin disinfectant in Sri lanka, cetrimide and chlorhexidine have been shown to be equally or more effective. In most studies chlorhexidine was found to be more effective than povidone-iodine for an immediate reduction in skin flora and also provided better long term bacterial suppression. ${ }^{4}$ Use of $2 \%$ chlorhexidine for skin disinfection before insertion of an intravascular device reduces the incidence of device related infection. ${ }^{5}$ No recent study has been carried out in a hospital setting in Sri Lanka to evaluate the efficacy of skin disinfectants using these antiseptics and to determine the prevalence of contamination among the new and multi use bottles of antiseptics. This study was carried out with the above mentioned objectives to generate data in this area.

\section{Materials and Methods}

\section{Disinfectants}

Three hospital disinfectants used in the study were ; $10 \%$ povidone iodine (Betadine), 1\% cetrimide (Cetavlon) and a solution containing $1.5 \% \mathrm{w} / \mathrm{v}$ chlorhexidine gluconate, $15 \% \mathrm{w} / \mathrm{v}$ cetrimide and $4 \% \mathrm{v} / \mathrm{v}$ isopropyl alcohol. This solution was diluted 1:30 before use as a skin disinfectant. $10 \mathrm{ml}$ aliquots of disinfectants from previously used bottles and newly opened bottles of all disinfectants were collected using a sterile needle and syringe and sent to the laboratory in sterile bottles for In-use test to detect contamination of bottles.

\section{Patients}

The study was an observational randomized study conducted between April 2005 to August 2006. The study population consisted of 80 pregnant women who received spinal or epidural anaesthesia at De Zoysa Maternity Hospital, Colombo and Castle Street Hospital for Women, Colombo. They were randomly assigned to receive skin preparation with Betadine, Cetavlon or the combined preparation consisting of chlorhexidine, cetrimide and iso propyl alcohol. Two skin swabs for culture were obtained from each subject; just prior to skin disinfection and immediately following disinfection. Patients were excluded if they had fever $>99^{\circ} \mathrm{F}$ had received antibiotics within 48 hours, had immunocompromising diseases such as Diabetes or HIV infection, were obese and had preexisting skin infection. Ethical clearence for the study was obtained from the ethical committee, University of Colombo. Informed consent was obtained from all patients engaged in the study.

\section{Skin Disinfection and specimen collection}

Skin disinfection was carried out by the principal investigator or the practicing anaesthetic Medical Officer or Registrar in charge of the procedure. Aseptic precautions were used during the procedure. The hands of the doctor carrying out the procedure were scrubbed following standard method, and sterile gown and gloves worn. Patient was seated on the theater table and the target area $\left(10 \mathrm{~cm}^{2}\right)$ was disinfected using the selected disinfectant solution. The solution was applied on the skin for one minute and another swab was taken for culture. To maintain the homology of the sample collection, each anaesthetist who volunteered to collect specimens for the study was verbally instructed on skin disinfection method and sample collection technique. Sterile cotton swabs wetted with sterile saline was used for collecting the two skin swabs; one prior to disinfection and the other immediately after skin disinfection. The cotton swab was carefully rubbed over a $5 \mathrm{~cm}^{2}$ area of 
the skin preparation site. The swab was then inserted into sterile Stuarts transport medium and sent to the laboratory for culture. Swabs were not allowed to touch the area that had not been disinfected. Strict aseptic techniques were followed during collection of swabs. After taking both swabs the target site was cleaned again with Betadine for one minute followed by application of isopropyl alcohol before administering spinal or epidural injection.

\section{Microbiological investigations}

The swabs were transferred under aseptic conditions into tubes containing $1 \mathrm{ml}$ sterile saline. These tubes were vortexed for 30 - 60 seconds to suspend the organisms. $100 \mu \mathrm{l}$ of 1:100 dilution of each suspension was inoculated to Blood agar and Nutrient agar plates. The plates were incubated at $37^{\circ} \mathrm{C}$ for upto 72 hours and were examined daily for growth. The number of bacterial colonies present on the plates before and after application of disinfection were counted manually and recorded as log Colony forming units/ml $(\log \mathrm{CFU} / \mathrm{ml})$.

In-use test was performed to determine bacterial contamination of newly opened and multiple used bottles from each group as has been described before ${ }^{6}$. In brief each disinfectant solution was first diluted 1:10 in sterile nutrient broth. $20 \mu \mathrm{l}$ of diluted disinfectant solution is spotted 10 times/disinfectant bottle on sterile nutrient agar and incubated at $37^{\circ} \mathrm{C}$ for upto 3 days. The plate is observed for growth on the spotted area. Observation of bacterial growth in more than 5 /10 drops for each tested disinfectant solution was taken to indicate failure of disinfection.

\section{Data analysis}

The sample size was not equal in all three groups. To evaluate the ability of each disinfectant to significantly reduce the number of bacterial colony forming units following application of disinfectant, paired one tailed T-test was applied. The log reduction of bacterial CFU following skin preparation between the three groups were tested by one way ANOVA. T-test was used to do a pair wise comparison to determine the log reduction of skin flora following disinfection and to determine which antiseptic showed highest reduction of bacterial counts.

\section{Results}

\section{Subject characteristics}

The patients enrolled to all three groups were similar with respect to age, weight and parity. All patients were ASA I. Fifty six patients received spinal anaesthesia while 24 patients received epidural anaesthesia in this study. Thirty six patients were included in Betadine group (45\%), 28 patients in Cetavlon group (35\%) and 16 patients in the combined preparation consisting of chlorhexidine, cetrimide and iso propyl alcohol (20\%). Betadine was used at both hospitals while Cetavlon was used only at De Soyza Maternity Hostpital (DMH), and the combined preparation was available in Castle Street Hospital for Women. (CSHW)

\section{Ability of the disinfectants to reduce the bacterial burden.}

The results of swab cultures taken before and after application of antiseptic is given in Table 1. All three disinfectant solutions were able to reduce the skin flora significantly following application on skin $(\mathrm{p}<0.05)$. In the Betadine group no growth was obtained after application of disinfectants in $44 \%$ of patient samples. In the Cetavlon group and combined preparation group the percentage of patients yielding no growth following application of disinfectants were $50 \%$.

\section{Table 1.}

Positive skin cultures obtained from patients whose skin was prepared for spinal or epidural injection by (group a) $10 \%$ povidone iodine, (group b) $2 \%$ cetrimide and (group c) combined preparation

\begin{tabular}{|l|l|l|l|}
\hline & $\begin{array}{l}\text { Povidione } \\
\text { lodine } \\
(\mathrm{n}=36)\end{array}$ & $\begin{array}{l}\text { Cetavlon } \\
(\mathrm{n}=28)\end{array}$ & $\begin{array}{l}\text { Combined } \\
\text { preparation } \\
(\mathrm{n}=16)\end{array}$ \\
\hline $\begin{array}{l}\text { Mean of log CFU/ml } \\
\text { before disinfection } \\
\text { (Mean+/-Standard } \\
\text { Deviation) }\end{array}$ & $\begin{array}{l}3.23+/- \\
1.3\end{array}$ & $2.64+/-1.2$ & $3.55+/-1.3$ \\
\hline $\begin{array}{l}\text { Mean of log CFU/ml } \\
\text { after disinfection } \\
\text { (Mean+/-Standard } \\
\text { Deviation) }\end{array}$ & $\begin{array}{l}1.31+/- \\
1.4\end{array}$ & $0.92+/-1.1$ & $0.88+/-1.0$ \\
\hline P value & $\mathrm{P}<0.001$ & $\mathrm{P}<0.001$ & $\mathrm{P}<0.001$ \\
\hline
\end{tabular}

The log reduction of bacterial colony forming units following application of disinfectant was calculated for each patient and the values obtained were compared in all three groups by one way ANOVA and was found to be significant $(p=0.018)$. As this indicates that the three groups are different in the ability to reduce the bacterial 
burden, further statistical investigations were carried out by comparing two disinfectant groups at a time to determine if there was a statistical significance in the ability of these disinfectants to reduce the number of bacteria on skin. Table 2 gives the result of the pair wise comparison of the log reduction of bacterial colony forming units of the three disinfectant groups. There was no statistical significance in the Log reduction $\mathrm{CFU} / \mathrm{ml}$ between povidone iodine + Cetavlon groups $(p=0.46)$. However statistical significance was seen when $\log$ reduction of $\mathrm{CFU} / \mathrm{ml}$ was compared between povidone iodine + combined preparation $(\mathrm{p}=0.02)$ and Cetavlon + combined preparation $(\mathrm{p}=0.003)$.

Table 2.

Pairwise comparison of the Log reduction in colony forming units $/ \mathrm{ml}$ following application of disinfectants on skin.

\begin{tabular}{|l|l|}
\hline $\begin{array}{l}\text { Disinfectant groups compared by log } \\
\text { reduction CFU/ml }\end{array}$ & $\mathrm{P}$ value \\
\hline Povidone lodine group + Cetavlon group & $\mathrm{P}=0.46$ \\
\hline $\begin{array}{l}\text { Povidone Iodine group + combined } \\
\text { preparation group }\end{array}$ & $\mathrm{P}=0.02$ \\
\hline $\begin{array}{l}\text { Cetavlon group + Combined preparation } \\
\text { group }\end{array}$ & $\mathrm{P}=0.003$ \\
\hline
\end{tabular}

In order to determine the disinfectant with the best ability to reduce the bacterial burden the values of percentage reduction for each disinfectant was compared. All three disinfectants were able to reduce over $90 \%$ of the bacterial burden on skin following disinfection. However the combined preparation could reduce the bacterial burden over 99\%. Thus in our study the combined preparation gave the highest reduction in bacterial flora as compared to povidone iodine and Cetavlon.

Table 3.

Percentage reduction of bacterial colony forming units/ml by the three disinfectants studied.

\begin{tabular}{|l|l|}
\hline Disinfectant & $\begin{array}{l}\text { Percentage reduction of } \\
\text { bacterial colony forming } \\
\text { units / ml }\end{array}$ \\
\hline povidone iodine & $90.7 \%$ \\
\hline Cetavlon & $94.7 \%$ \\
\hline Combined preparation & $99.2 \%$ \\
\hline
\end{tabular}

\section{Rate of contamination in new and multi use} bottles of disinfectants

Antiseptic contents of 32 both newly opened and multi use bottles of disinfectants were tested for contamination by the In-use test. 50\% of the samples tested were from CSHW and remaining from DMH. None of the bottles tested, which were newly opened on day of collection (new bottles) or which were opened previously and had been used more than once (multi use bottles) from all three groups of disinfectants yielded any growth. There was no contamination detected in multi use bottles.

\section{Discussion}

Our results indicate that all three disinfectants tested in this study were able to significantly reduce the skin flora by over $90 \%$. Of the three disinfectants the combined preparation gave the highest reduction in skin flora (99\%). The combined preparation consists of chlorhexidine gluconate, cetrimide and isopropyl alcohol.

In our study we were not able to detect any microbial growth in the bottles of disinfectants tested. This may be due to the fact that actual number of disinfectant bottles tested was less than 10 for each group and may not reveal the true picture. Bimbach et al (1998) reported a prevalence of contamination of povidone iodine bottles as $40 \%{ }^{3}$. Thus in the Sri Lankan operation theatre setting a larger sample number should be evaluated for detection of contamination of disinfectant bottles. As we were not able to obtain data on the day of first use of some disinfectant bottles used for skin disinfection further analysis was not possible to determine the average number of days of use and correlate it to the reduction in bacterial burden.

The combined preparation which gave the best reduction in bacterial flora, consisted of chlorhexidine which is a cationic biguanide. The disinfectant chlorhexidine has a broad spectrum of activity against bacteria and some viruses. Resistance to chlorhexidine has been reported by some Gram negative bacteria. ${ }^{7}$ However adaptation to grow in chlorhexidine based disinfectant solutions have been reported by Serratia marcescens. ${ }^{8}$ The disinfectant chlorhexidine is available as commercial formulations together with other disinfecting 
agents like ethanol and detergents, and such a formulation was tested by us. The mode of action of chlorhexidine may be that the cationic disinfectant disrupts the lipoprotein cell membrane thereby disrupting its function as an osmotic barrier. ${ }^{9}$ In most studies chlorhexidine was found to be more effective than povidone iodine for an immediate reduction in skin flora and also provided better long term bacterial suppression ${ }^{10}$. This is in agreement with our study where the combined disinfectant containing chlorhexidine was found to be of the highest effectiveness in reducing the bacterial burden. Use of $2 \%$ chlorhexidine for skin disinfection before insertion of an intravascular device reduces the incidence of device related infection. ${ }^{11}$

The disinfectant povidone iodine, tested by us belongs to the class of iodophores which are iodine releasing agents which are more stable than iodine. Iodine rapidly penetrates into microorganisms and attacks key groups of proteins, nucleotides and fatty acids resulting in cell death. However bacteria like Pseudomonas cepacia have been reported to have survived in povidone iodine solutions up to 68 weeks ${ }^{12}$. The disinfectant povidone iodine may not completely remove bacteria from skin and the duration of its effectiveness is limited. Previously opened multi use bottles have been reported to have decreased activity against skin flora ${ }^{3}$. However in our study we did not see a significant difference between the effectiveness of newly opened and multi use bottles of povidone iodine (Data not shown). In a recent study where $10 \%$ povidone iodine was used for skin disinfection skin colonization was reduced to $3.5 \%$ but risk for contamination of needles and catheters during epidural catheterization was significant ${ }^{13}$. In another study, effect of $0.5 \%$ chlorhexidine ethanol and $10 \%$ povidone-iodine was similar in reducing catheter colonization ${ }^{14}$. Birnbach et al (2003) suggests that addition of alcohol to iodinated disinfection or use of a simple alcohol swab following povidone iodine antisepsis improved skin antisepsis and limited colonization of epidural catheter ${ }^{15}$.

The disinfectant cetrimide (Cetavlon) tested by us is a cationic detergent belonging to the group of quarternary ammonium compounds. These are membrane active agents with a target site predominantly at the inner cytoplasmic membrane in bacteria. The action of cetrimide may result in loss of structural organization and integrity of the cytoplasmic membrane resulting in cell lysis ${ }^{12}$. In literature not much data is available on the usefulness of ctent cetrimide as a skin disinfectant. In our study we report that $1 \%$ cetrimide solution showed 94\% reduction in bacterial burden following application on the skin.

\section{Conclusion}

No recent study has been carried out in a hospital setting in Sri Lanka to evaluate the efficacy of skin disinfection using the three disinfectants tested by us, and to determine the prevalence of contamination among the new and multiple use bottles of antiseptics. In our study we report that none of the antiseptic bottles tested showed bacterial colonization. The combined preparation (chlorhexidine, cetrimide and isopropyl alcohol) showed best reduction in bacterial counts followed by $1 \%$ cetrimide and Betadine $(10 \%$ povidone iodine).

\section{Acknowledgements}

We like to thank Dr. (Mrs) A. Warnakulasuriya and Dr. (Mrs) Saroja Jayasinghe (Consultant anaesthetists), Anaesthetic Registrars, Medical Officers and theatre staff at CSHW and DMH for the invaluable corporation extended to us during the period of this study. We also thank Mrs L.D. Guruge (Technical officer), Mr K.G.A. Kapuella and $\mathrm{Mr}$ V.P.P. Wasantha, Department of Microbiology, University of Sri Jayawardenepura for their support in preparation of material for specimen collection.

\section{References}

1. Sato S, Sakuragi T, Dan K. Human skin flora as a potential source of epidural abscess. Anesthesiology 1996;85(6):1276-82

2. Kinirons B, Mimoz O, Lafendi L, Naas T, Meunier J, Nordmann P. Chlorhexidine versus Povidone Iodine in preventing colonization of continuous epidural catheters in children. Anesthesiology 2001:94:239-44

3. Bimbach DJ, Stein DJ, Murray O, Thys DM, Sordillo EM. Povidone iodine and skin disinfection before initiation of Epidural Anesthesia. Anesthesiology 1998;88(3):668-72 
4. Ayliffe GAJ, Babb JR, Davies JG, Lilly HA. Hand disinfection : a comparison of various agents in laboratory and ward studies. J Hosp Infect 1989;11:226-43

5. Maki DG, Ringer M and CJ Alvarado. Prospective randomized trial of Povidone-Iodine, alcohol and chlorhexidine for prevention of infection associated with central venous and arterial catheters. The Lancet 1991;338:339-43

6. White AB.(1996) Sterilization and Disinfection. In Mackie \& McCartney Practical Medical Microbiology. Colee JG, Fraser AG, Marmion BP and A Simmons (eds), 14 ${ }^{\text {th }}$ Edition Churchill Livingstone London p: 813-834

7. Thomas B, Sykes L and DJ Stickler. Sensitivity of urine grown cells of Providencia stuartii to antiseptics. Journal of Clinical Pathology 1978;31:929-32

8. Gandhi PA, Sawant AD, Wilson LA, Aheam DG. Adaptation and growth of Serratia marcescens in contact lens disinfectant solutions containing Chlorhexidine gluconate. Applied and Environmental Microbiology 1993; 59(1):183-8

9. Hugo WB and AR Longworth. Some aspects of the mode of action of chlorhexidine. Journal of Pharmacy and Pharmacology 1964; 16:655-62

10. Ayliffe GAJ, Babb JR, Davies JG, Lilly HA. Hand disinfection : a comparison of various agents in laboratory and ward studies. J Hosp Infect 1989;11:226-43

11. Maki DG, Ringer $M$ and CJ Alvarado. Prospective randomized trial of Povidone-Iodine, alcohol and chlorhexidine for prevention of infection associated with central venous and arterial catheters. The Lancet 1991;338:339-43

12. McDonnall $G$ and AD Russell. Antiseptics and Disinfectants : Activity Action and Resistance. Clinical Microbiology Reviews 1999;12(1):147-79

13. Yentur EA, Luleci N, Topcu I, Degerli K, Surucuoglu S. Is skin disinfection with $10 \%$ Povidone Iodine sufficient to prevent epidural needle and catheter contamination ? Reg Anesth Pain Med. 2003; 28(5):389-93

14. Kasuda H, Fukuda H, Togashi J, Hotta K, Hirai Y, Hayashi M. Skin disinfection before epidural catheterization: comparative study of povidoneiodine versus chlorhexidine ethanol. Dermatology 2002; 204 Suppl 1:42-6

15. Bimbach DJ, Meadowns W, Stein DJ, Murray O, Thys DM, Sordillo EM. Comparison of Povidone Iodine and DruaPrep, an iodophor-in-Isopropyl Alcohol solution, for skin disinfection prior to epidural catheter insertion in parturients. Anesthesiology 2003;98:164-9

\section{LECTURE DEMONSTRATION \& CERTIFICATION}

$$
\text { ON }
$$

\section{Cardio Pulmonary Resuscitation}

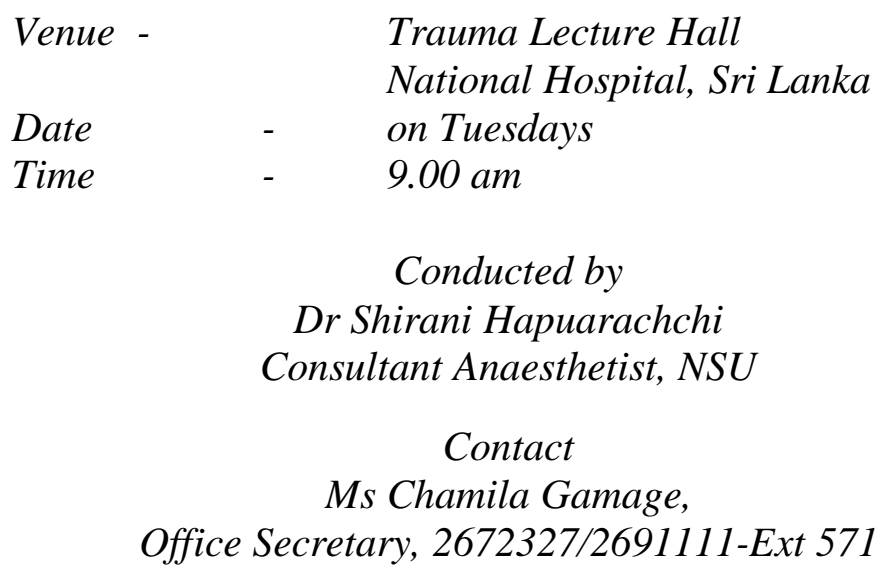

